\title{
Guanine Nucleotide-Binding Protein Subunit Alpha-13
}

National Cancer Institute

\section{Source}

National Cancer Institute. Guanine Nucleotide-Binding Protein Subunit Alpha-13. NCI

Thesaurus. Code C115330.

Guanine nucleotide-binding protein subunit alpha-13 (377 aa, $\sim 44 \mathrm{kDa}$ ) is encoded by the human GNA13 gene. This protein plays a role in heterotrimeric G protein-mediated signal transduction. 